\title{
PENGARUH FAKTOR KEPRIBADIAN WIRAUSAHA TERHADAP \\ INTENSI BERWIRAUSAHA PADA MAHASISWA AKUNTANSI \\ Studi pada mahasiswa Akuntansi Universitas Ahmad Dahlan Yogyakarta
}

\author{
Budi Barata \\ Kurniawan Ali Fachrudin
}

\begin{abstract}
Many studies suggest that personality factors determining the entrepreneurship intentions. On the other hand, entrepreneurship education is one way to increase student entrepreneurship intentions. Another personality factor that can improve student entrepreneurship intention is risk-taking propensity and locus of control. The purpose of this study is to find empirical evidence about the influence of personality factors as seen from education entrepreneurship, risktaking propensity, and locus of control on entrepreneurial intentions of students of the Faculty of Economics of Accounting Studies Program University of Ahmad Dahlan Yogyakarta. The data used are primary data where the sample was taken based on purposive sampling as many as 100 students of Accounting Ahmad Dahlan University Yogyakarta. Regression analysis was used to test research hypotheses with the help of SPSS 16. Research results showed that entrepreneurship education and locus of control affect the entrepreneurial intention, while the trend did not affect the risk-taking entrepreneurial intentions. Based simultaneous test ( $F$ test) variables entrepreneurship education, risk taking propensity, locus of control and influence on entrepreneurial intentions.
\end{abstract}

Keywords: entrepreneurship education, risk taking propensity, locus of control, entrepreneurship intentions.

\section{PENDAHULUAN}

Pengangguran di Indonesia semakin hari semakin meningkat jumlahnya seiring dengan berjalannya waktu. Para pencari kerja baik yang mempunyai gelar sarjana ataupun tidak harus bersaing untuk mendapatkan pekerjaan pada lapangan kerja yang terbatas. Adapun penyebab masalah pengangguran terdidik adalah banyak sarjana bertujuan hanya mencari pekerjaan, bukan menciptakan lapangan pekerjaan. Menjadi seorang wirausaha merupakan salah satu pendukung yang menentukan maju mundurnya perekonomian, karena bidang wirausaha mempunyai kebebasan untuk berkarya dan mandiri. Wirausaha inilah yang mampu menciptakan lapangan kerja baru agar mampu menyerap tenaga kerja (Oktarili: 2010). 
Menurut Kourilsky dan Walstad dalam Indarti dan Rostiani (2008) pengaruh pendidikan kewirausahaan selama ini telah dipertimbangkan sebagai salah satu faktor penting untuk menumbuhkan dan mengembangkan hasrat, jiwa dan perilaku berwirausaha di kalangan generasi muda. Terkait dengan pendidikan kewirausahaan tersebut, diperlukan adanya pemahaman dalam mengembangkan dan mendorong lahirnya wirausaha muda yang potensial, beberapa penelitian sebelumnya menyebutkan bahwa keinginan berwirausaha para mahasiswa merupakan sumber bagi lahirnya wirausaha-wirausaha masa depan (Kourilsky dan Walstad, 1998 dalam Indarti dan Rostiani, 2008). Kourilsky dan Walsta dalam Indarti dan Rostiani (2008) menyatakan sikap, prilaku dan pengetahuan mereka tentang kewirausahaan akan membentuk kecenderungan mereka untuk membuka usaha-usaha baru di masa mendatang.

Kourilsky dan Walstad dalam Sinarasri dan Hanum (2012) mengemukakan bahwa pengaruh pendidikan kewirausahaan selama ini telah dipertimbangkan sebagai salah satu faktor penting untuk menumbuhkan dan mengembangkan hasrat, jiwa dan perilaku berwirausaha di kalangan generasi muda. Terkait dengan pendidikan kewirausahaan tersebut, diperlukan adanya tentang pemahaman dalam mengembangkan dan mendorong lahirnya wirausaha muda yang potensial.

Murgianto dalam Triawan dan Sumaryono (2008) menyatakan bahwa hambatan eksternal dalam pengembangan kewirausahaan pada suatu wilayah atau negara dapat berupa sistem dan kebijakan yang dijalankan pemerintah yang menghambat tumbuh dan berkembangnya minat dan bibit-bibit kewirausahaan. Sementara itu, hambatan internal, selain faktor keterbatasan pengetahuan, ketrampilan dan kemampuan berwirausaha yang dimiliki lulusan sekolah menengah atas dan perguruan tinggi, juga faktor psikologis. Rendahnya minat berwirausaha disebabkan tidak adanya keberanian untuk mengambil risiko dalam mencoba atau memulai suatu usaha sendiri karena ada perasaan takut akan kegagalan sehingga mereka cenderung menunggu mendapatkan pekerjaan di sektor pemerintahan atau sektor swasta dibanding menciptakannya sendiri.

Suryana (2007) menyatakan seorang wirausaha harus berani menghadapi risiko. Semakin besar risiko yang dihadapinya, semakin besar pula kesempatan 
untuk meraih keuntungan. Hal ini dikarenakan jumlah pemainnya sedikit. Kita ketahui bahwa menjadi seorang wirausaha bukanlah mudah, proses berwirausaha melibatkan tidak hanya pemecahan masalah dalam bidang manajemen tertentu, tetapi juga dalam pengambilan risiko. Misalnya menghasilkan dan menjual produk baru atau membuka cabang baru selalu dihadapkan pada ketidakpastian seperti apakah produk baru dapat memenuhi selera dan kebutuhan konsumen atau apakah permintaan yang cukup besar sehingga cabang baru perlu dibuka.

\section{TINJAUAN PUSTAKA DAN PENGEMBANGAN HIPOTESIS}

\section{Pendidikan Kewirausahaan}

Wasty dalam Wibowo (2011) mengutarakan bahwa pendidikan adalah daya upaya untuk membantu perkembangan seluruh aspek kepribadian manusia sehingga dengan demikian manusia dapat mengusahakan kehidupannya sendiri. Manusia pada hakekatnya merupakan pribadi yang berkembang mengikuti hukum serta kekuatan kodrati yang telah dianugerahkan Tuhan.

Scarborough dan Zimmerer dalam Handriani (2011) mendefinisi kewirausahaan sebagai orang-orang yang memiliki kemampuan melihat dan menilai kesempatan bisnis, mengumpulkan sumber daya yang dibutuhkan untuk mengambil tindakan yang tepat, mengambil keuntungan serta memiliki sifat, watak dan kemauan untuk mewujudkan gagasan inovatif kedalam dunia nyata secara kreatif dalam rangka meraih sukses atau meningkatkan pendapatan.

Pendidikan kewirausahaan adalah usaha terencana dan aplikatif untuk meningkatkan pengetahuan, intensi dan kompetensi peserta didik untuk mengembangkan potensi dirinya dengan diwujudkan dalam prilaku kreatif, inovatif dan berani mengelola risiko (www.ekonomi.kompasiana.com, 2013). Sutrisno dalam Wibowo (2011) menyatakan bahwa yang namanya pendidikan berwawasan kewirausahaan adalah pendidikan yang menerapkan prinsip-prinsip dan metodologi ke arah pembentukan kecakapan hidup (life skill) pada peserta didiknya melalui kurikulum yang terintegrasi. Hipotesis yang diajukan adalah:

$\mathrm{H}_{1 \text { : }}$ Pendidikan kewirausahaan berpengaruh terhadap intensi berwirausaha pada mahasiswa akuntansi. 


\section{Kecenderungan Pengambilan Risiko}

Wojowasito (1976) berpendapat bahwa kecenderungan diterjemahkan dari kata tendency. Menurut Lado (1991) kecenderungan diartikan suatu kecenderungan ke arah tertentu. Poerwadarminto (1976) mengatakan bahwa kecenderungan berasal dari kata cenderung yang berarti ingin atau suka. Dengan demikian kecenderungan merupakan perbuatan yang condong akan dilakukan oleh seseorang (www.id.shvoong.com, 2013).

British Medical Association dalam Kurniawan (2011) mengintrepretasi risiko sebagai kemungkinan terjadinya sesuatu kejadian yang tidak diharapkan atau yang tidak menyenangkan. Riyanti (2007) dalam Kurniawan (2011) menambahkan bahwa segala perilaku muncul ketika seseorang dihadapkan pada situasi risiko dapat dijelaskan dengan konsep perilaku pengambilan risiko.

Yates (1994) dalam Kurniawan (2011) menjelaskan pengambilan risiko adalah bagaimana seseorang berprilaku dalam situasi berisiko, di mana situasi ini mengandung tingkat ketidakpastian tinggi dan kemungkinan kerugian. Fishcoff dalam Kurniawan (2011) menjelaskan bahwa dalam mempelajari pengambilan risiko seharusnya mempertimbangkan bahwa pengambilan risiko mungkin sebagai proses pengambilan keputusan yang meliputi beberapa aktivitas seperti adanya identifikas kemungkinan perilaku dan konsekuensi yang akan terjadi, penilaian akan menarik atau tidaknya konsekuensi tersebut serta kombinasi dari segala penilaian dan pilihan atas kombinasi itu. Hipotesis yang diajukan adalah:

$\mathrm{H}_{2}$ : Kecenderungan pengambilan risiko berpengaruh terhadap intensi berwirausaha pada mahasiswa akuntansi.

\section{Locus of control}

Locus of control merupakan suatu keyakinan mengenai sumber kontrol dari penguat (reinforcement). Rotter dalam Pratiwi (2011: 6) menjelaskan bahwa locus of control merupakan salah satu variabel kepribadian yang didefinisi sebagai keyakinan individu terhadap mampu tidaknya individu mengontrol nasib (destiny) sendiri. Selanjutnya, Rotter dalam Pratiwi (2011: 6) menyatakan bahwa locus of control, baik internal maupun eksternal, merupakan tingkatan seorang individu 
yang berharap bahwa reinforcement atau hasil dari perilaku mereka tergantung pada perilaku mereka sendiri atau karakteristik personal mereka.

Berdasar literatur akuntansi, locus of control adalah cara pandang seseorang terhadap suatu peristiwa apakah dia dapat atau tidak dapat mengendalikan (control) peristiwa yang terjadi pada dirinya (Rotter dalam Pratiwi, 2011). Menurut Larsen dalam Pratiwi (2011: 6) locus of control merupakan suatu konsep yang menunjuk pada keyakinan individu mengenai sumber kendali akan peristiwaperistiwa yang terjadi dalam hidupnya. Locus of control menggambarkan seberapa jauh seseorang memandang hubungan antara perbuatan yang dilakukannya (action) dengan akibat atau hasilnya (outcome).

Variabel kepribadian yang berkaitan dengan harapan umum seseorang terhadap kemampuannya untuk mengontrol peristiwa-peristiwa dalam kehidupan dikenal sebagai locus of control. Selanjutnya, Rotter dalam Pratiwi (2011: 6) menyatakan bahwa locus of control baik internal maupun eksternal, merupakan tingkatan seorang individu yang berharap bahwa hasil dari perilaku mereka tergantung pada perilaku mereka sendiri atau karakteristik personal mereka. Beberapa karakteristik yang melekat pada diri wirausaha salah satunya adalah locus of control. Individu memiliki kemampuan menghadapi rintangan akan memiliki locus of control yang tinggi sehingga berpotensi dalam berwirausaha (Kristiansen, 2001 dalam Kurniawan 2011). Hipotesis yang diajukan adalah:

$\mathrm{H}_{3}$ : Locus of control berpengaruh terhadap intensi berwirausaha pada mahasiswa akuntansi.

\section{Intensi Berwirausaha}

Intensi didefinisi sebagai dimensi probabilitas subjektif individu dalam kaitan antara diri dan perilaku. Intensi merupakan perkiraan seseorang mengenai seberapa besar kemungkinan untuk melakukan tindakan tertentu. Bandura dalam Wijaya (2007: 119) menyatakan bahwa intensi merupakan suatu kebulatan tekad untuk melakukan aktivitas tertentu atau menghasilkan suatu keadaan tertentu di masa depan.

Katz dan Gartner (1988) dalam Kurniawan (2011) intensi berwirausaha dapat diartikan sebagai proses pencarian informasi yang dapat digunakan untuk 
mencapai tujuan pembentukan suatu usaha. Wijaya (2007) menyatakan bahwa salah satu faktor wirausaha adalah adanya keinginan dan keinginan ini oleh Fishbein dan Ajzen dalam Wijaya (2007) disebut sebagai intensi yaitu komponen dalam diri individu yang mengacu pada keinginan untuk melakukan tingkah laku tertentu.

\section{METODA PENELITIAN}

\section{Populasi dan Sampel}

Populasi penelitian ini adalah mahasiswa Universitas Ahmad Dahlan dari Fakultas Ekonomi Program Studi Akuntansi. Mahasiswa yang menjadi sampel dalam penelitian ini adalah mahasiswa yang dipilih berdasarkan metoda purposive sampling, yaitu pemilihan sampel sesuai dengan kriteria tertentu. Populasi sasaran sebanyak 530 mahasiswa akuntansi. Besarnya sampel yang digunakan dalam penelitian ini adalah 100 responden.

Teknik pengumpulan data yang akan digunakan dalam penelitian ini adalah teknik angket (kuesioner) dan skala yang digunakan adalah skala Likert, yaitu skala yang berisi empat tingkat preferensi jawaban dengan pemberian skor berjenjang.

\begin{tabular}{|c|c|c|c|c|}
\hline Preferensi & Sangat Setuju & Setuju & Tidak Setuju & Sangat Tidak Setuju \\
\hline Favourable & 5 & 4 & 2 & 1 \\
\hline Unfavourable & 1 & 2 & 4 & 5 \\
\hline
\end{tabular}

\section{DEFINISI OPERASIONAL VARIABEL}

\section{Pendidikan kewirausahaan $\left(\mathrm{X}_{1}\right)$}

Pendidikan kewirausahaan adalah usaha terencana dan aplikatif untuk meningkatkan pengetahuan, intensi dan kompetensi peserta didik untuk mengembangkan potensi dirinya dengan diwujudkan dalam prilaku kreatif, inovatif, dan berani mengelola risiko (www.ekonomi.kompasiana.com, 2013). Indikator pendidikan kewirausahaan dilihat dari materi kewirausahaan yang diberikan dalam perkuliahan. Mengutip dari Rahman (2010) pendidikan kewirausahaan diukur dengan indikator: 
1. Gagasan produk baru.

2. Motivasi untuk berwirausaha.

3. Kerjasama tim dalam berwirausaha.

4. Mampu membuat analisis strenght, weakness, opportunity dan threatness.

5. Etika binis dan tanggung jawab sosial.

6. Kemampuan business life skill.

7. Mampu mengelola permodalan.

\section{Kecenderungan pengambilan risiko $\left(\mathbf{X}_{2}\right)$}

British Medical Association dalam Kurniawan (2011) mengintrepretasi risiko sebagai kemungkinan terjadinya sesuatu kejadian yang tidak diharapkan atau yang tidak menyenangkan. Riyanti dalam Kurniawan (2011) menambahkan bahwa segala perilaku muncul ketika seseorang dihadapkan pada situasi risiko dapat dijelaskan dengan konsep perilaku pengambilan risiko.

\section{Locus of control $\left(\mathrm{X}_{3}\right)$}

Locus of control didefinisi sebagai suatu ilmu karakter yang menerangkan perbedaan individu dalam sebuah kepercayaan yang digeneralisasikan dalam kekuatan pengendalian internal dan pengendalian eksternal. Instrumen yang digunakan dalam penelitian ini adalah instrumen yang dikembangkan oleh Pratiwi (2011).

\section{Intensi berwirausaha}

Fishbein dan Ajzen dalam Wijaya (2007) mengemukakan bahwa intensi merupakan komponen dalam diri individu yang mengacu pada keinginan untuk melakukan tingkah laku tertentu. Ramayah dan Harun (2005) dalam Andika dan Madjid (2012) mendefinisi intensi berwirausaha sebagai tendensi keinginan individu untuk melakukan tindakan wirausaha dengan menciptakan produk baru melalui peluang bisnis dan pengambilan risiko. Intensi berwirausaha ini diukur dengan menggunakan skala aspek-aspek intensi berwirausaha terdiri dari:

1. Memilih berwirausaha daripada berkerja pada orang lain.

2. Memilih berkarir sebagai wirausahawan. 
3. Melakukan perencanaan untuk memulai usaha.

4. Meningkatkan status sosial dan harga diri sebagai wirausaha.

5. Mendapatkan pendapatan yang lebih baik.

\section{PEMBAHASAN}

\section{Statistik Deskriptif}

Statistik deskriptif memberikan gambaran atau deskripsi suatu data yang dilihat dari nilai rata-rata, deviasi standar, nilai minimum, dan maksimum serta range. Berikut hasil pendiskripsian statistik deskriptif:

Tabel 1

Deskripsi Variabel

\begin{tabular}{|l|c|c|c|c|c|c|}
\hline \multicolumn{1}{|c|}{ Variabel } & $\begin{array}{c}\text { Kisaran } \\
\text { teoretis }\end{array}$ & $\begin{array}{c}\text { Nilai } \\
\text { tengah }\end{array}$ & $\begin{array}{c}\text { Rata- } \\
\text { rata }\end{array}$ & Minimal & Maksimal & $\begin{array}{c}\text { Deviasi } \\
\text { standar }\end{array}$ \\
\hline $\begin{array}{l}\text { Pendidikan } \\
\text { kewirausahaan }\end{array}$ & $9-45$ & 27 & 38,01 & 10 & 45 & 3,99620 \\
\hline $\begin{array}{l}\text { Kecenderungan } \\
\text { pengambilan } \\
\text { risiko }\end{array}$ & $4-20$ & 12 & 14,52 & 6 & 20 & 4,01633 \\
\hline $\begin{array}{l}\text { Locus of } \\
\text { control }\end{array}$ & $8-40$ & 24 & 31,80 & 11 & 40 & 4,85815 \\
\hline $\begin{array}{l}\text { Intensi } \\
\text { berwirausaha }\end{array}$ & $6-30$ & 18 & 25,86 & 8 & 30 & 2,97131 \\
\hline
\end{tabular}

Sumber: Data primer, diolah 2013

Tabel 1 menunjukkan bahwa variabel pendidikan kewirausahaan mempunyai nilai rata-rata 38,01 nilai minimal 10 dan nilai maksimal 45 dengan deviasi standar 3,99620 dan nilai tengahnya 27. Variabel kecenderungan pengambilan risiko mempunyai nilai rata-rata 14,52 nilai minimal 6 dan nilai maksimal 20 dengan deviasi standar 4,01633 dan nilai tengahnya 12. Variabel locus of control mempunyai nilai rata-rata 38,01 nilai minimal 11 dan nilai maksimal 40 dengan deviasi standar 4,85815 dan nilai tengahnya 24. Variabel intensi berwirausaha mempunyai nilai rata-rata 25,86 nilai minimal 8 dan nilai maksimal 30 dengan deviasi standar 2,97131 dan nilai tengahnya 18.

Variabel penelitian diklasifikasikan ke dalam tiga kategori yaitu tinggi, sedang, dan rendah. Cara untuk menentukan kategori yaitu dengan menentukan 
besarnya nilai rentang skala dengan cara data skor terbesar dikurangi dengan data skor terkecil dan dibagi dengan tiga.

Tabel 2

Kategori Variabel

\begin{tabular}{|c|l|c|c|c|c|c|c|}
\hline No & \multicolumn{1}{|c|}{ Variabel } & Miksimal & Minimal & $\begin{array}{c}\text { Rentang } \\
\text { skala }\end{array}$ & $\begin{array}{c}\text { Rata- } \\
\text { rata }\end{array}$ & $\begin{array}{c}\text { Nilai } \\
\text { Tengah }\end{array}$ & Kategori \\
\hline 1. & $\begin{array}{l}\text { Pendidikan } \\
\text { kewirausahaan }\end{array}$ & 10 & 45 & 11,67 & 38,01 & 27 & Tinggi \\
\hline $\begin{array}{l}\text { 2. } \\
\text { Kecenderungan } \\
\text { pengambilan } \\
\text { risiko }\end{array}$ & 6 & 20 & 4,67 & 14,52 & 12 & Sedang \\
\hline 3. & $\begin{array}{l}\text { Locus of } \\
\text { control }\end{array}$ & 11 & 40 & 9,67 & 31,80 & 24 & Tinggi \\
\hline 4. & $\begin{array}{l}\text { Intensi } \\
\text { berwirausaha }\end{array}$ & 8 & 30 & 7,33 & 25,86 & 18 & Tinggi \\
\hline
\end{tabular}

Sumber: Data primer, diolah 2013

\section{Uji Validitas}

Uji validitas digunakan untuk mengukur sah atau tidaknya suatu kuesioner. Suatu kuesioner dikatakan valid jika pertanyaan pada kuesioner mampu untuk mengungkapkan suatu yang akan diukur oleh kuesioner tersebut. Pengujian validitas kuesioner dilakukan dengan confirmatory factor analysis/CFA (Ghozali, 2011: 52).

Alat uji lain yang digunakan untuk mengukur tingkat interkorelasi antar variabel dan dapat tidaknya dilakukan analisis faktor adalah Kaiser-Meyer-Olkin measure sampling adquacy. Nilai Kaiser-Meyer-Olkin measure sampling adquacy harus > 0,50 untuk dapat dilakukan analisis faktor (Ghozali, 2011: 58). 
Tabel 3

Uji Validitas Pendidikan Kewirausahaan

\begin{tabular}{|c|c|c|c|c|c|c|}
\hline \multirow[b]{2}{*}{ Variabel } & \multicolumn{4}{|c|}{ Hasil Analisis } & \multirow{2}{*}{$\begin{array}{l}\text { Kaiser- } \\
\text { Meyer- } \\
\text { Olkin } \\
\text { (KMO) }\end{array}$} & \multirow[b]{2}{*}{ Keterangan } \\
\hline & & \multicolumn{3}{|c|}{ Component Matrix } & & \\
\hline \multirow{9}{*}{$\begin{array}{c}\text { Pendidikan } \\
\text { Kewirausahaan }\end{array}$} & Pertanyaan 1 & 0,680 & $-0,036$ & $-0,634$ & \multirow{9}{*}{0,770} & \multirow{9}{*}{$\begin{array}{c}\text { Tidak valid, } \\
\text { maka } \\
\text { pertanyaan } \\
\text { Pertanyaan } \\
8 \text { dan } 9 \\
\text { dihapus. }\end{array}$} \\
\hline & Pertanyaan 2 & 0,683 & 0,087 & $-0,606$ & & \\
\hline & Pertanyaan 3 & 0,746 & $-0,188$ & 0,005 & & \\
\hline & Pertanyaan 4 & 0,753 & $-0,303$ & 0,238 & & \\
\hline & Pertanyaan 5 & 0,688 & $-0,181$ & 0,094 & & \\
\hline & Pertanyaan 6 & 0,694 & $-0,207$ & 0,288 & & \\
\hline & Pertanyaan 7 & 0,673 & $-0,268$ & 0,320 & & \\
\hline & Pertanyaan 8 & 0,510 & 0,750 & 0,217 & & \\
\hline & Pertanyaan 9 & 0,533 & 0,748 & 0,137 & & \\
\hline
\end{tabular}

Sumber: Data primer, diolah (2013).

Tabel 4

Uji Validitas Kecenderungan Pengambilan Risiko

\begin{tabular}{|c|c|c|c|c|}
\hline \multirow[b]{2}{*}{ Variabel } & \multicolumn{2}{|r|}{ Hasil Analisis } & \multirow{2}{*}{$\begin{array}{l}\text { Kaiser- Meyer- } \\
\text { Olkin }(\text { KMO })\end{array}$} & \multirow[b]{2}{*}{ Keterangan } \\
\hline & & $\begin{array}{l}\text { Component } \\
\text { Matrix }\end{array}$ & & \\
\hline \multirow{4}{*}{$\begin{array}{l}\text { Kecenderungan } \\
\text { pengambilan } \\
\text { risiko }\end{array}$} & Pertanyaan 1 & 0,860 & \multirow{4}{*}{0,674} & \multirow{4}{*}{ Valid } \\
\hline & Pertanyaan 2 & 0,881 & & \\
\hline & Pertanyaan 3 & 0,860 & & \\
\hline & Pertanyaan 4 & 0,871 & & \\
\hline
\end{tabular}

Sumber: Data primer, diolah (2013). 
Tabel 5

Uji Validitas Locus of Control

\begin{tabular}{|c|c|c|c|c|c|}
\hline \multirow[b]{2}{*}{ Variabel } & \multicolumn{3}{|c|}{ Hasil } & \multirow{2}{*}{$\begin{array}{c}\text { Kaiser- } \\
\text { Meyer- } \\
\text { Olkin } \\
(\text { KMO })\end{array}$} & \multirow[b]{2}{*}{ Keterangan } \\
\hline & & \multicolumn{2}{|c|}{ Component Matrix } & & \\
\hline \multirow{8}{*}{$\begin{array}{c}\text { Locus of } \\
\text { control }\end{array}$} & Pertanyaan 1 & 0,733 & 0,149 & \multirow{8}{*}{0,808} & \multirow{8}{*}{$\begin{array}{c}\text { Tidak valid, } \\
\text { maka } \\
\text { pertanyaan } \\
\text { VAR00004 } \\
\text { dihapus }\end{array}$} \\
\hline & Pertanyaan 2 & 0,727 & $-0,383$ & & \\
\hline & Pertanyaan 3 & 0,745 & 0,120 & & \\
\hline & Pertanyaan 4 & 0,550 & 0,610 & & \\
\hline & Pertanyaan 5 & 0,660 & $-0,416$ & & \\
\hline & Pertanyaan 6 & 0,688 & $-0,344$ & & \\
\hline & Pertanyaan 7 & 0,583 & 0,528 & & \\
\hline & Pertanyaan 8 & 0,536 & $-0,097$ & & \\
\hline
\end{tabular}

Sumber: Data primer, diolah (2013).

\section{Uji Reliabilitas}

Uji reliabilitas ini menggunakan reliabilitas konsistensi internal yaitu tekhnik Cronbach Alpha $(\alpha)$. Apabila nilai Cronbach alpha dari hasil pengujian $>$ 0,6 maka dapat dikatakan bahwa konstruk atau variabel itu adalah reliabel (Nunnaly, 1969 dalam Ghozali, 2001).

Tabel 6

Uji Reliabilitas

\begin{tabular}{|l|c|c|}
\hline \multicolumn{1}{|c|}{ Variabel } & Cronbach Alpha & Keterangan \\
\hline Pendidikan kewirausahaan & 0,844 & Reliabel \\
\hline Kecenderungan pengambilan risiko & 0,891 & Reliabel \\
\hline Locus of control & 0,791 & Reliabel \\
\hline
\end{tabular}

Sumber: Data primer, diolah (2013).

Hasil Cronbach Alpha pada tabel 6 menunjukkan bahwa variabel pendidikan kewirausahaan, kecenderungan pengambilan risiko dan locus of control menunjukan nilai Cornbach Alpha yang berada diatas 0,6. Dengan demikian, masing-masing variabel tersebut reliabel. 


\section{Uji Normalitas}

Uji normalitas bertujuan untuk menguji dalam model regresi, variabel pengganggu atau residual memiliki distribusi normal (Ghozali, 2011: 160). Uji statistik lain yang dapat digunakan untuk menguji normalitas residual adalah uji statistik nonparametrik Kolmogorof-Smirnov (K-S). Uji K-S dilakukan dengan melihat nilai dari asymp.Sig. (2-tailed). Jika nilai asymp. Sig. (2-tailed)> 0,05 maka residual berdistribusi normal.

Tabel 7

Uji Normalitas

\begin{tabular}{|l|c|c|}
\hline \multicolumn{1}{|c|}{ Keterangan } & $\begin{array}{c}\text { Unstandardized } \\
\text { Residual }\end{array}$ & $\begin{array}{c}\text { Tingkat } \\
\text { Kepercayaan }(\boldsymbol{\alpha})\end{array}$ \\
\hline N & 100 & \multirow{2}{*}{0,05} \\
\cline { 1 - 2 } Asymp. Sig. (2- tailed) & 0,443 & \\
\hline
\end{tabular}

Sumber: Data primer, diolah (2013).

Hasil uji normalitas menunjukkan bahwa nilai Asymp. Sig. (2-tailed) sebesar 0,443. Karena signifikansi di atas 0,05 $(0,443>0,05)$, maka nilai residual ersebut normal.

\section{Uji Multikolinieritas}

Ghozali (2011: 105) uji multikolinieritas bertujuan untuk menguji model regresi ditemukan adanya korelasi antar variabel bebas (independen). Model regresi yang baik seharusnya tidak terjadi korelasi di antara variabel independen. Jika variabel independen saling berkorelasi, maka variabel-variabel ini tidak ortogonal. Variabel ortogonal adalah variabel independen yang nilai korelasi antara sesama variabel independen sama dengan nol. Multikolinieritas dapat dilihat dari (1) nilai tolerance dan lawannya (2) variance inflation factor (VIF).

Tabel 8

Uji Multikolinearitas

\begin{tabular}{|l|c|c|}
\hline \multirow{2}{*}{\multicolumn{1}{|c|}{ Variabel }} & \multicolumn{2}{c|}{ Collinearity statistics } \\
\cline { 2 - 3 } & Tolerance & VIF \\
\hline Pendidikan kewirausahaan & 0,849 & 1,178 \\
\hline Kecenderungan pengambilan risiko & 0,944 & 1,059 \\
\hline Locus of control & 0,897 & 1,115 \\
\hline
\end{tabular}

Sumber: Data primer, diolah (2013). 
Hasil uji multikolinieritas menunjukkan bahwa tidak ada variabel independen yang memiliki nilai tolerance kurang dari 1 dan tidak ada variabel independen yang memiliki nilai variance inflation factor (VIF) lebih dari 10. Sehingga dapat disimpulkan bahwa antar variabel independen tidak terjadi persoalan multikolinearitas.

\section{Uji Heteroskedastisitas}

Ghozali (2011: 139) uji heteroskedastisitas bertujuan menguji dalam model regresi terjadi ketidaksamaan variance dari residual satu pengamatan ke pengamatan yang lain. Jika variance dari residual satu pengamatan ke pengamatan lain tetap, maka disebut homoskedastisitas dan jika berbeda disebut heteroskedastisitas. Model regresi yang baik adalah yang homoskedastisitas atau tidak terjadi heteroskedastisitas. Uji heteroskedastisitas dilakukan dengan uji Glejser.

Tabel 9

Uji Heteroskedastisitas

\begin{tabular}{|l|c|c|}
\hline \multicolumn{1}{|c|}{ Variabel } & $\begin{array}{c}\text { Nilai } \\
\text { signifikansi }\end{array}$ & $\begin{array}{c}\text { Tingkat } \\
\text { kepercayaan }(\boldsymbol{\alpha})\end{array}$ \\
\hline Pendidikan kewirausahaan & 0,481 & 0,05 \\
\hline $\begin{array}{l}\text { Kecenderungan pengambilan } \\
\text { risiko }\end{array}$ & 0,864 & 0,05 \\
\hline Locus of control & 0,116 & 0,05 \\
\hline
\end{tabular}

Sumber: Data primer, diolah 2013

Hasil uji heteroskedastisitas menunjukkan nilai signifikansi ketiga variabel independen lebih dari 0,05. Sehingga dapat disimpulkan bahwa tidak terjadi masalah heteroskedastisitas pada model regresi.

\section{Uji Autokorelasi}

Uji autokorelasi bertujuan menguji dalam model regresi linier ada korelasi antara kesalahan penggangu pada perioda t dengan kesalahan pengganggu pada perioda t-1 (sebelumnya). Jika terjadi korelasi, maka dinamakan ada problem autokorelasi. Autokorelasi muncul karena observasi yang berurutan sepanjang waktu berkaitan satu sama lainnya. Masalah ini timbul karena residual (kesalahan 
penggangu) tidak bebas dari satu observasi ke observasi lainya. Teknik pengujian autokorelasi adalah uji Durbin-Watson (DW test). Uji Durbin-Watson hanya digunakan untuk autokorelasi tingkat satu (first order autocorrelation) dan mensyaratkan adanya intercept (konstanta) dalam model regresi dan tidak ada variabel lagi di antara variabel independen (Ghozali, 2011: 110-111).

\section{Tabel 10}

\section{Uji Autokorelasi}

\begin{tabular}{|c|c|c|}
\hline Durbin-Watson (DW) & Du & 4-Du \\
\hline 2,093 & 1,736 & 2,264 \\
\hline
\end{tabular}

Sumber: Data primer, diolah (2013).

Nilai Durbin-Watson (DW) sebesar 2,093, nilai ini dibandingkan dengan nilai tabel dengan menggunakan nilai signifikansi 5\%, jumlah sampel 100 (n) dan jumlah variabel tiga $(\mathrm{k}=3)$, maka didapat batas bahwa (dL) 1,693 dan batas atas (dU) 1,736, karena nilai (DW) lebih besar dari (dU) 1,736 dan kurang dari (4-dU) 4-1,736 maka dapat disimpulkan bahwa tidak terdapat auto korelasi positif maupun negatif pada model regresi.

\section{Analisis Regresi Berganda}

Tabel 11

Analisis Regresi Berganda

\begin{tabular}{|l|c|c|c|}
\hline \multirow{2}{*}{ Model } & \multicolumn{2}{|c|}{ Unstandardized Coefficients } & \\
\cline { 2 - 4 } & B & Std. Error & Nilai signifikansi \\
\hline Constanta & 5,840 & 2,238 & \\
\hline Pendidikan kewirausahaan & 0,500 & 0,073 & 0,00 \\
\hline $\begin{array}{l}\text { Kecenderungan pengambilan } \\
\text { risiko }\end{array}$ & 0,029 & 0,057 & 0,606 \\
\hline Locus of control & 0,196 & 0,065 & 0,00 \\
\hline
\end{tabular}

Sumber: Data primer, diolah (2013).

Dengan memperhatikan hasil regresi linier berganda tersebut maka didapat model regresi linier berganda sebagai berikut:

$Y=5,840+0,500 X+0,000 X+0,196 X+e$ 


\section{Uji R $\mathbf{R}^{2}$ (Koefisien Determinasi)}

Tabel 12

Uji Koefisien Determinasi

\begin{tabular}{|c|c|c|}
\hline $\mathbf{R}$ & $\boldsymbol{R}$ Square & Adjusted $\boldsymbol{R}$ Square \\
\hline $0.680^{\mathrm{a}}$ & 0,463 & 0,446 \\
\hline
\end{tabular}

Sumber: Data primer, diolah (2013).

Tabel 12 menunjukkan besarnya adjusted $R$ square adalah 0,446 , hal ini berarti 44,6\% intensi berwirausaha dapat dijelaskan oleh variasi dari ketiga variabel independen (pendidikan kewirausahaan, kecenderungan pengambilan risiko, dan locus of control). Sedangkan sisanya $(100 \%-44,6 \%=55,4)$ dipengaruhi oleh variabel lain yang tidak dimasukkan dalam model penelitian ini.

\section{Uji F}

\section{Tabel 13}

\begin{tabular}{|c|c|}
\multicolumn{2}{c}{ Uji F } \\
\hline F & Nilai Signifikansi \\
\hline 27.551 & $0,000^{\mathrm{a}}$ \\
\hline
\end{tabular}

Sumber: Data primer, diolah (2013).

Tabel 13 menunjukkan nilai $\mathrm{F}$ hitung sebesar 27,551 dengan nilai signifikansi 0,000. Karena nilai siginifikansi jauh lebih kecil dari 0,05, maka model regresi dapat digunakan untuk memprediksi intensi berwirausaha atau dapat dikatakan bahwa minimal ada satu variabel independen yang berpengaruh terhadap variabel dependen.

\section{Uji t}

\section{Tabel 14}

\begin{tabular}{|l|c|c|}
\hline \multicolumn{1}{|c|}{ Uji t } \\
& $\begin{array}{c}\text { Nilai } \\
\text { Signifikansi }\end{array}$ & $\begin{array}{c}\text { Tingkat } \\
\text { kepercayaan }(\boldsymbol{\alpha})\end{array}$ \\
\hline Pendidikan kewirausahaan & 0,000 & 0,05 \\
\hline Kecenderungan pengambilan risiko & 0,606 & 0,05 \\
\hline Locus of control & 0,004 & 0,05 \\
\hline
\end{tabular}

Sumber: Data primer, diolah (2013). 
Tabel 14 menunjukkan hasil perhitungan regresi linier berganda pada variabel pendidikan kewirausahaan menunjukan nilai signifikansi $0,000<0,05$ maka $\mathrm{H}_{1}$ diterima. Hasil pergitungan regresi linier berganda pada variabel kecenderungan pengambilan risiko menunjukan nilai siginifikansi 0,606 $>0,05$ maka $\mathrm{H}_{2}$ tidak dapat diterima. Hasil perhitungan regresi linier berganda pada

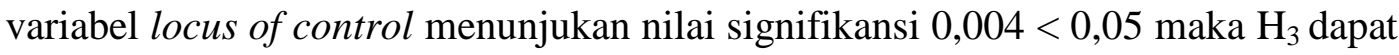
diterima.

\section{SIMPULAN, KETERBATASAN, DAN SARAN}

Hasil penelitian ini disimpulkan bahwa :

1. Pendidikan kewirausahaan berpengaruh terhadap intensi berwirausaha pada mahasiswa akuntansi.

2. Kecenderungan pengambilan risiko tidak berpengaruh terhadap intensi berwirausaha pada mahasiswa akuntansi.

3. Locus of control berpengaruh terhadap intensi berwirausaha pada mahasiswa akuntansi.

Penelitian ini memiliki keterbatasan sebagai berikut :

1. Karena keterbatasan waktu dalam pencarian instrumen terdahulu maka ketidaksiapan instrumen dalam penelitian ini menjadi keterbatasan. Peneliti membuat sendiri instrumen untuk penelitian ini terutama untuk variabel pendidikan kewirausahaan dan kecenderungan pengambilan risiko.

2. Penelitian terdahulu dengan ketiga variabel seperti penelitian ini masih sangat jarang dilakukan sehingga untuk penemuan teori-teori yang akan diungkapkan dalam penelitian ini juga masih terbatas.

3. Selain itu dapat diketahui bahwa pengaruh ketiga variabel independen (pendidikan kewirausahaan, kecenderungan pengambilan risiko dan locus of control) berpengaruh terhadap variabel dependen (intensi berwirausaha) sebesar $44,6 \%$ dan sisanya sebesar $54,4 \%$ dipengaruhi oleh variabel lain di luar penelitian ini.

Berdasar keterbatasan yang ada dalam penelitian ini, maka saran yang berikan untuk penelitian selanjutnya adalah : 
1. Penelitian mendatang dapat memperluas jangkauan penelitiannya, karena penelitian ini dibatasi hanya pada Universitas Ahmad Dahlan Yogyakarta saja, sehingga dapat melihat perbedaan antar universitas.

2. Penelitian mendatang dapat mengembangkan penelitiannya dengan menambahkan faktor lainnya. Hal ini berarti masih banyak variabel lain yang mempengaruhi intensi berwirausaha yang bisa diteliti. Faktor tersebut seperti lingkungan dan demografi.

\section{DAFTAR PUSTAKA}

Ghozali, Imam. 2001. Aplikasi Analisis Multivariate dengan Program SPSS (edisi 1). Semarang. Badan Penerbit Universitas Dipenogoro.

Ghozali, Imam. 2011. Aplikasi Analisis Multivariate dengan Program IBM SPSS 19 (edisi 1). Semarang. Badan Penerbit Universitas Dipenogoro.

Handriani, Eka. 2011. Pengembangan Kualitas Pendidikan Kewirausahaan di Perguruan Tinggi. Semarang. Universitas Undaris Ungaran Jurnal Ilmiah Inkoma Vol. 22 Nomor 1.

Indarti, Nurul., dan rostiani, Rokhima. 2008. Intensi Kewirausahaan Mahasiswa: Studi Perbandingan antara Indonesia, Jepang, dan Norwegia. Yogyakarta. Jurnal Ekonomika dan Bisnis Indonesia, Vol. 23, No. 4, Oktober 2008 Universitas Gajah Mada.

Kurniawan, Teddy Djuliarki. 2011. Intensi Berwirausaha Siswa Sekolah Menengah Kejuruan (SMK) Negeri 22 Jakarta: Peran Self Efficacy, LoC, Risk Taking Behavior, EQ, dan AQ. Jakarta. Universitas Islam Negeri Syarif Hidayatullah.

Oktarili, Nur Shabrina. 2010. Pengaruh Faktor-Faktor yang dapat Memotivasi Mahasiswa Berkeinginan Wirausaha. Jakarta. Universitas Gunadarma (tidak dipublikasikan).

Pratiwi, Wahyuni Indras. 2011. Pengaruh Locus of Control, Komitmen Profesi, Kepuasan Kerja, Sistem Kompensasi serta Sikap Independensi terhadap Perilaku Auditor dalam menghadapi konflik audit. Yogyakarta. Universitas Ahmad Dahlan (tidak dipublikasikan). 
Rahman, Fathur. 2010. Silabus dan RPP Kewirausahaan. Yogyakarta. Universitas Negeri Yogyakarta.

Sinarasri, Adwiani dan Hanum, Ayu Noviani. 2012. Pengaruh Latar Belakang Pendidikan terhadap Motivasi Kewirausahaan Mahasiswa (Studi Kasus pada Mahasiswa UNIMUS di Semarang). Semarang. Universitas Muhammadiyah Semarang (Seminar Hasil-Hasil Penelitian-LPPM UNIMUS).

Sumaryono dan Triawan. 2008. Kecenderungan Perilaku Pengambilan Resiko. Yogyakarta. Psikologia Edisi 26 Vol. 13 Tahun 2008 Universitas Gajah Mada.

Suryana. 2007. Kewirausahaan Pedoman Praktis, Kiat dan Menuju Sukses.Jakarta. Salemba Empat.

Wibowo, Muladi. 2011. Pembelajaran Kewirausahaan dan Minat Wirausaha Lulusnan SMK. Surakarta. Universitas Islam Batik. Eksplanasi Volume 6 Nomor 2.

Wijaya, Tony.2007. Hubungan Advesity Intellegence dengan Intensi Berwirausaha (Studi Empiris pada Siswa SMKN 7 Yogyakarta). Yogakarta. STTI Respati Jurnal Manajemen dan Kewirausahaan Vol. 9.

www://ekonomi.kompasiana.com [online] <wirausaha/pendidikan-kewirausahaanentrepreneurship-education--533892.html [3> April 2013]

www://id.shvoong.com [online] social-sciences/counseling/2205683-pengertian kecenderungan-kecanduan-mengakses-internet.html [20> Maret 2013] 